\title{
Pelatihan Pembuatan Es Krim Buah Naga Sebagai Upaya Peningkatan Gizi Keluarga bagi Kader PKK Kadipiro Banjarsari Surakarta
}

\author{
Reslely Harjanti, Siti Aisiyah, Vivin Nopiyanti, Titik Sunarni, Suhartinah \\ Universitas Setia Budi Surakarta \\ res_ley@yahoo.co.id
}

\begin{abstract}
Key word:
Training;

dragon fruit;

Ice cream;

Antioxidant

Kata Kunci

Pelatihan;

buah naga;

es krim;

antioksidan

\section{Abstract}

The community and especially children really like snacks such as ice cream. The use of dragon fruit as a component in ice cream is expected to be able to make people enjoy the sweetness and also get the intake of anthocyanins, especially those with antioxidant properties. The purpose of this activity is to provide skills training in the use of dragon fruit as the main component for ice cream making to PKK members in Kadipiro sub-district, Banjarsari District, Surakarta. The service activity begins with an explanation of the usefulness of dragon fruit and its phytochemical content. After that it was continued with training in making ice cream to PKK members. The training activities were divided into several stages starting from the tutorial then continued with mentoring from the team and ended with an evaluation of the implementation of the activities. The results from this activity are 1) participants have the understanding about nutrition of dragon fruit; 2) They understand procedure to make home made dragon fruit ice cream; 3) they able to make ice cream by themselves.

Abstrak

Masyarakat dan anak-anak pada khususnya sangat suka jajanan seperti es krim. Pemanfaatan buah naga sebagai komponen dalam es krim diharapkan dapat mengkondisikan selain menikmati rasa manisnya juga memperoleh asupan zat antosianinnya terutama yang berkhasiat antioksidan. Tujuan dari program kegiatan pengabdian masyarakat ini adalah memberikan pelatihan ketrampilan dalam pemanfaatan buah naga sebagai komponen utama untuk pembuatan es krim kepada kader PKK kelurahan Kadipiro Kecamatan Banjarsari Surakarta. Kegiatan pengabdian diawali dengan penjelasan tentang kemanfaatan buah naga serta kandungan fitokimianya. Setelah itu dilanjutkan dengan pelatihan pembuatan es krim kepada para kader PKK. Kegiatan pelatihan dibagi dalam beberapa tahapan dimulai dari tutorial kemudian dilanjutkan dengan pendampingan dari tim pengabdi dan diakhiri dengan evaluasi pelaksanaan kegiatan. Hasil dari kegiatan ini adalah 1) peserta memiliki pemahaman tentang nutrisi buah naga; 2) Mereka memahami prosedur membuat es krim buah naga buatan sendiri; 3) mereka dapat membuat es krim sendiri.
\end{abstract}




\section{PENDAHULUAN}

Es krim adalah sebuah makanan beku dibuat dari produk susu seperti krim (atau sejenisnya), digabungkan dengan perasa dan pemanis. Es krim merupakan makanan padat dan beku dengan tekstur yang lembut dan memiliki nilai gizi yang tinggi serta digemari oleh masyarakat. Menurut Standar Nasional Indonesia Nomor 01-3713-1995 es krim didefinisikan sebagai makanan semi padat yang dibuat dengan cara pembekuan campuran susu lemak hewani maupun nabati, gula dengan atau tanpa bahan makanan lain dan bahan makanan yang diizinkan. Syarat mutu yang telah ditetapkan untuk es krim yaitu mengandung lemak minimal 5\%, gula yang dihitung sebagai sukrosa minimal $8 \%$, protein minimal $2,7 \%$, dan padatan minimal 3,4\% (SNI, 1995).

Ditinjau dari kandungan gizi, es krim mengandung kalsium, fosfor, protein, vitamin, dan mineral. Kandungan kalsium dan fosfor pada es krim bermanfaat untuk menjaga kepadatan massa tulang, pencegahan osteoporosis, kanker, serta hipertensi. Protein merupakan zat penting yang diperlukan seseorang untuk memperbaiki jaringan otot yang digunakan. Nutrisi es krim terdapat pada kandungannya yang berasal dari susu yaitu vitamin A, D, K dan B12. Vitamin A baik untuk kesehatan mata anak. Sehingga dapat disimpulkan bahwa es krim merupakan produk makanan yang enak yang sesuai untuk anak terutama yang susah makan agar dapat mencukupi kebutuhan gizi yang dibutuhkan oleh anak terutama pada masa pertumbuhan.

Produk es krim umumnya menggunakan bahan cita rasa untuk lebih meningkatkan selera kita misalnya rasa durian, strowberi dan coklat. Buah naga dapat dijadikan sebagai salah satu pilihan yang tepat untuk menambah keanekaragaman cita rasa es krim.

Jenis buah naga (Dragon fruit) ada empat, antara lain buah naga berdaging putih (Hylocereus undatus), buah naga berdaging merah (Hylocereus polyrhizus), buah naga berdaging super merah (Hylocereus costaricensis), dan buah naga berkulit kuning dengan daging putih (Selenicereus megalanthus). Kandungan gizi buah naga (Dragon fruit) adalah: Protein 0,159-0,229 g, Lemak 0,21-0,61 g, Serat Kasar 0,7-0,9 g, Karoten 0,005-0,012 g, Kalsium 6,3-8,8 mg, Fosfor 30,2-36,1 mg, Iron 0,55-0,65 mg, Vitamin B1 0,280,034 mg, Vitamin B2 0,043-0,045 mg, Vitamin B3 0,297-0,43 mg, Vitamin C 8-9 g, Thiamine $0,28-0,30 \mathrm{mg}$, Riboflavin 0,043-0,044 mg, Niacin 1,297-1,300 mg, Abu 0,28 g. Vitamin C yang berfungsi untuk menjaga kesehatatan dan sangat membantu meningkatkan daya tahan tubuh dan 
melancarkan metabolisme (Winarsih, 2007).

Buah naga merah (Hylocereus polyrhizus) mengandung polifenol, antosianin dan betasianin. Tumbuhan ini tergolong dalam famili Cactaceae dan subfamili Cactoideae. Antosianin adalah zat warna alami golongan flavonoid yang tersebar luas di alam. Senyawa antosianin memberikan warna merah pada buah naga. Zat warna antosianin bersifat tidak stabil dan mudah terdegradasi. Stabilitasnya dipengaruhi oleh $\mathrm{pH}$, suhu penyimpanan, cahaya, enzim, oksigenasi, perbedaan struktur dalam antosianin dan konsentrasi dari antosianin.

$$
\text { Umayah dan Amrun }
$$
melaporkan bahwa buah naga mempunyai aktivitas antiradikal di mana ekstrak air dengan konsentrasi $4,49 \%$ (setara dengan 3,08 $\mathrm{g}$ buah naga segar) dan hasil pengujian aktivitas antiradikal bebas, menunjukkan bahwa eksrak metanol dengan konsentrasi $64,68 \%$ (setara dengan 49,6 $\mathrm{g}$ buah naga segar). Buah naga juga mempunyai aktivitas antikolesterol yaitu menghambat enzim HMG Coa Reductase, sehingga konsentrasi kolesterol yang terdapat di liver dan plasma normal (Valery et al., 2011) Antosianin bekerja menghambat CETP sehingga terjadi peningkatan kadar HDL kolesterol dan penurunan kadar LDL (Qin et al., 2009).
Kegiatan pengabdian pada masyarakat merupakan implementasi hasil penelitian yang telah dilaksanakan oleh civitas akademika. Pelaksanakan kegiatan pengabdian pada masyarakat dapat memberikan dampak positif dalam meningkatkan kesejahteraan masyarakat. Tema pengabdian yang dipilih adalah terkait dengan hasil penelitian tentang aktivitas farmakologis dari buah naga serta pemanfaatan dan analisis produk susu dan olahannya yang telah dilakukan di laboratorium analisis makanan Universitas Setia Budi.

\section{METODE PEMECAHAN MASALAH}

Pelaksanaan Kegiatan meliputi kegiatan persiapan sampai dengan pelaksanaan pelatihan dan monitoring pelatihan serta evaluasi kegiatan. Persiapan yang dilakukan meliputi observasi, perijinan maupun persiapan untuk penyuluhan dan pelatihan.

\section{HASIL}

Kegiatan pengabdian sudah dilaksanakan mulai dari tahap observasi, pelaksanaan sampai dengan monitoring dan evaluasi kegiatan. Kegiatan dilakukan dengan metode penjelasan materi dengan media ppt dan LCD serta cetak materi yang dibagikan kepada seluruh peserta. Setelah itu dilanjutkan dengan tutorial secara 
langsung tentang pembuatan es krim dengan komponen utama buah naga serta dilakukan monitoring dan evaluasi terhadap hasil pelatihan.

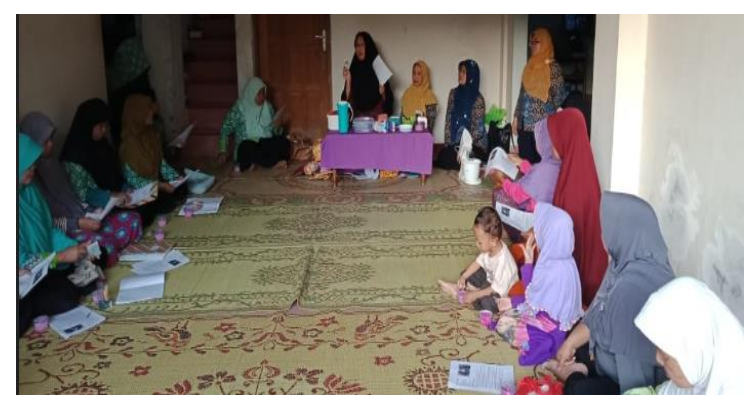

Gambar 1. Pelatihan tentang gizi dan nutrisi buah naga

\section{PEMBAHASAN}

Kegiatan pengabdian yang telah dilakukan dapat diterima oleh peserta dan dinilai sangat bermanfaat bagi warga para kader PKK khususnya di lingkungan Sukomulyo Kadipiro kecamatan Banjarsari kota Surakarta. Sesi kegiatan diskusi berlangsung kondusif dan kader PKK proaktif dalam tanya jawab.

Pada sesi tutorial disampaikan tentang cara pembuatan es krim dengan bahan dasar buah naga yang dinilai sangat berkhasiat dan pasti lebih aman. Zat warna merah pada daging buah naga mempunyai fungsi sebagai pewarna sekaligus sebagai sumber antioksidan alami sehingga aman untuk dikonsumsi dan dapat menjadi bagian dari upaya promosi kesehatan bagi keluarga dan masyarakat.

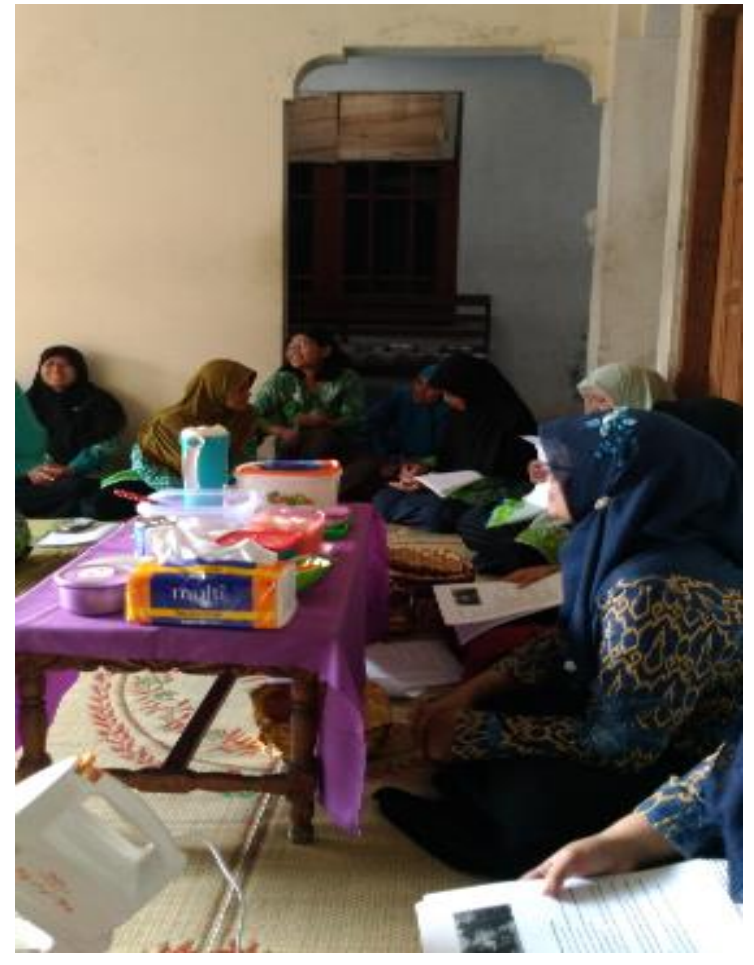

Gambar 2. Pelatihan tentang cara membuat es krim buah naga

Cara pembuatan es krim buah naga antara lain: (1) Dicampur dalam panci maizena, air, gula, garam, susu/susu kental manis dan vanili; (2) Dimasak dengan api kecil hingga kental saja (jangan encer, tetapi juga jangan terlalu kental/kenyal; (3) Dicicipi hingga tepung matang/tidak terasa getir. Dinginkan; (4) Disimpan adonan yang telah dingin di freezer hingga hampir beku. Kupas dan potong buah naga, dimasukkan ke dalam wadah dan dibekukan juga didalam frezer; (5) dicairkan SP dengan cara ditim (untuk mematangkan SP); (6) Diambil setengah bagian adonan yang telah beku dalam wadah untuk dimixer, lalu tambahkan setengah bagian SP yang telah ditim ke dalamnya. Sisa adonan yang tidak dimixer 
masukkan kembali ke dalam mixer; (7) Tusuk-tusuk atau cacah adonan beku dengan sendok agar lebih mudah untuk dimixer. Kemudian mixer adonan yang telah bercampur dengan SP dengan kecepatan rendah dulu; (8) Masukkan buah naga beku, kocok dengan kecepatan rendah. Setelah hancur sempurna naikkan kecepatan secara bertahap; (9) Adonan es krim dicicip untuk tes rasa. Jika kurang manis bisa ditambah dengan gula halus. Kemudian mixer hingga mengembang maksimal;(10) Masukkan adonan yang telah jadi ke dalam wadah tertutup dan disimpan ke dalam frezer.

Peserta melakukan praktik mandiri dengan pengawasan dan arahan dari tim pengabdi sehingga peserta memiliki kemampuan dan pemahaman untuk dapat membuat es krim sendiri di rumah masingmasing. Selain itu ketrampilan ini dapat dikembangkan menjadi usaha mandiri keluarga.

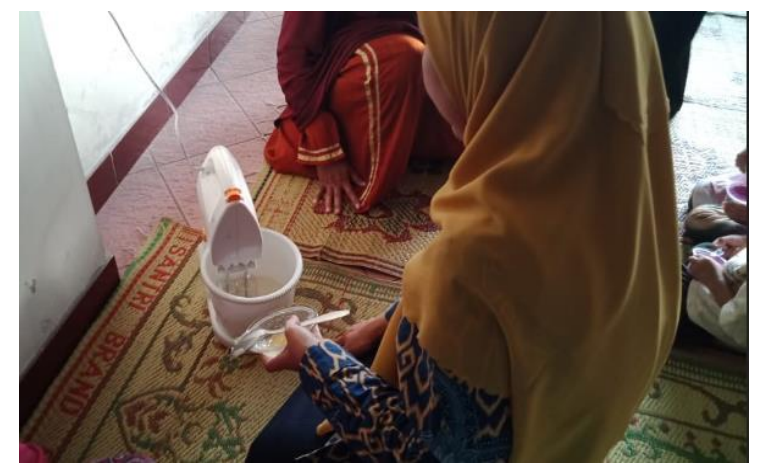

Gambar 3. Peserta melakukan praktik mendiri membuat es krim

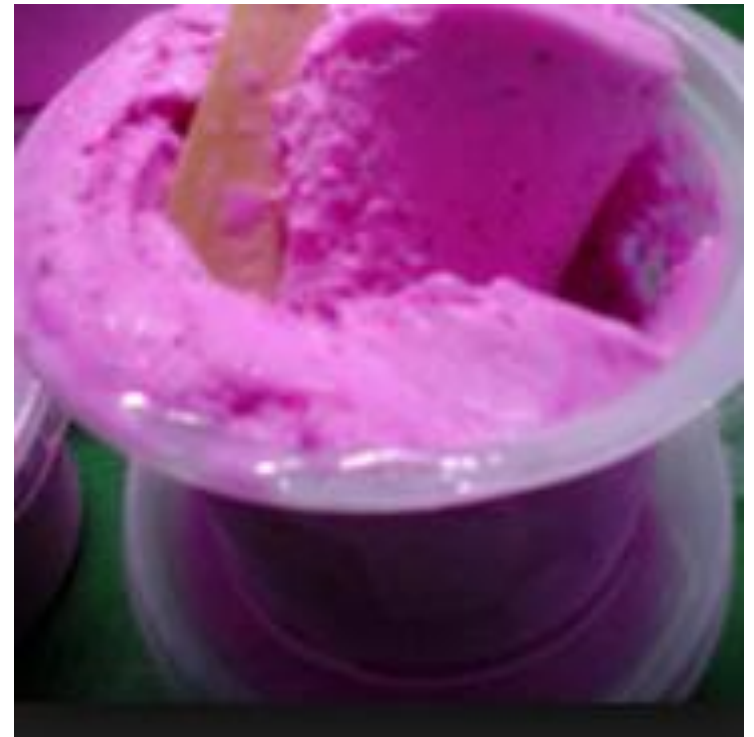

Gambar 4. Hasil jadi es krim buah naga

\section{KESIMPULAN}

Kegiatan pelatihan pembuatan es krim berbahan dasar buah naga yang telah dilaksanakan di lingkungan Sukomulyo Kadipiro, Banjarsari Surakarta bermanfaat bagi masyarakat khususnya kader PKK sehingga diharapkan dapat meningkatkan ketrampilan dalam upaya promosi kesehatan keluarga serta memberdayakan para peserta menuju kemandirian dalam upaya peningkatan kesejahteraan keluarga. Keterampilan yang diperoleh dari kegiatan ini dapat dikembangkan menjadi usaha mandiri warga.

\section{SARAN}

Peningkatan kapabilitas anggota PKK dapat dilanjutkan dengan pengabdian lanjutan dengan materi kemasan dan desain merk untuk es krim buah naga dan pemasarannya. 


\section{UCAPAN TERIMA KASIH}

Tim pengabdi menyampaikan terima kasih kepada Universitas Setia Budi yang telah mendanai kegiatan pengabdian kepada masyarakat ini serta kepada Bapak kepala kelurahan Kadipiro Banjarsari Surakarta yang telah memberikan perijinan serta masyarakat khususnya kader PKK di wilayah Sukomulyo Kadipiro yang telah berpartisipasi pada kegiatan pengabdian ini.

\section{DAFTAR PUSTAKA}

Dembitsky, V. M., Poovarodom, S., Leontowicz, H., Leontowicz, M., Vearasilp, S., Trakhtenberg, S., \& Gorinstein, S. (2011). The multiple nutrition properties of some exotic fruits: Biological activity and active metabolites. Food research international, 44(7), 1671-1701..

Evi, U. U., \& Amrun, M. H. (2007). Uji aktivitas antioksidan ekstrak buah naga Hylocereus undatus (Haw) Britt \& Rose. Jurnal Ilmu Dasar, 8(1), 8390.

Indonesia, S. N. (1995). SNI 01-37131995. Syarat Mutu Es Krim. Badan Standarisasi Nasional (BSN). Jakarta. Qin Y, Xia M, Ma J, Hao Y, Liu J, Mou H, Cao L, Ling W. (2009). Anthocyanin supplementation improves serum LDL and HDL cholesterol concentrations associated with the inhibition of cholesteryl ester transfer protein in dyslipidemic subjects, Am J Clin Nutr. : 90 (3):485492.

Winarsih, S. (2007). Mengenal dan Menbudidayakan Buah Naga. Aneka Ilmu. Semarang. 